\title{
Human Rights Education in Foreign Language Learning
}

\begin{abstract}
Today's world is marked by numerous violations of human rights. As teachers, we would like to believe that future violations can be prevented through human rights education which empowers individuals to build and promote a universal human rights culture. Young people should be given the chance to practise what it means to live together in an open and free society while at school; they, therefore, need to be equipped with a knowledge of human rights and the skills to put these rights into practice.
\end{abstract}

The paper addresses issues relating to including lessons on human rights into Slovene primary and secondary education as part of the foreign language learning syllabus, as well as the need to empower future teachers to react appropriately if their students reject other people's perspectives out of hand, or even express radical ideas in class that run contrary to democratic values. It also presents various strategies for enabling future teachers to develop the skills necessary to implement human rights education.

Keywords: human rights; education; personal development; foreign language learning

\section{Vključevanje učenja o človekovih pravicah $v$ učenje tujega jezika}

\section{POVZETEK}

Na osnovi aktualnih dogodkov lahko sklepamo, da današnji svet zaznamuje kršenje človekovih pravic. Učitelji verjamemo, da tovrstne kršitve lahko preprečimo z vključevanjem izobraževanja o človekovih pravicah tudi v pouk tujega jezika, ki omogoča posameznikom, da prispevajo $\mathrm{k}$ oblikovanju in širjenju splošne kulture človekovih pravic. Mladim moramo dati priložnost, da pri pouku doživljajo in spoznavajo, kaj pomeni živeti skupaj v odprti in svobodni družbi, zato jih moramo opremiti ne le s poznavanjem človekovih pravic, ampak tudi z znanjem o tem, kako si te pravice priboriti v vsakdanjem življenju.

Prispevek obravnava vključevanje učnih ur na temo človekovih pravic v slovensko osnovnošolsko in srednješolsko izobraževanje pri pouku tujega jezika in hkrati nakazuje potrebo po tem, da moramo bodoče učitelje usposobiti, da bodo ustrezno reagirali, če bodo njihovi učenci v razredu izražali radikalne ideje, ki nasprotujejo demokratičnim vrednotam ali pa preprosto neosnovano zavračali mnenja drugih. V nadaljevanju predstavi strategije, ki bodočim učiteljem omogočajo razvijanje kompetenc, potrebnih za izvajanje pouka, ki temelji na človekovih pravicah.

Ključne besede: človekove pravice; izobraževanje; osebni razvoj; učenje tujih jezikov 


\section{Human Rights Education in Foreign Language Learning}

\section{Introduction}

Every learner wants to be understood, respected, treated equally, and graded fairly. Being taught by a professional is one of our rights. Teacher education should, therefore, provide future teachers with the appropriate knowledge and skills to cater for various learners' needs and rights. The paper addresses two issues: first, including lessons on human rights into Slovene primary and secondary education as part of the foreign language learning syllabus and secondly, the need to empower future teachers to react professionally in addressing those needs. It presents various strategies for enabling future teachers to develop the skills necessary to implement human rights education (HRE). The paper is divided into four sections: the introductory section defines human rights education, learning through human rights and its relationship with peace education; the second section investigates how HRE principles are incorporated into Slovene legislation and the curricula, not only in Citizenship Education but also into other subjects. It also describes the initial stages of implementing these principles into lessons at primary and secondary level. The third section deals with addressing human rights issues in foreign language learning and provides some suggestions for human rights teaching activities; the fourth section discusses pre-service teacher training at the Faculty of Arts in Maribor and the tasks that enable student-teachers to develop the knowledge, skills and attitudes for critical interpretation and evaluation of their learners' beliefs and the behaviour which creates a framework for their professional practice.

According to the Universal Declaration of Human Rights, human rights are inherent to all human beings, regardless of national or ethnic origin, sex, religion, language or any other status. They are the foundation of equality, freedom, justice, and peace. The Universal Declaration, which has contributed to the development of human rights such as the freedom of expression, freedom of worship, freedom from want, and freedom from fear, was adopted in 1948. Since 2005, various policy documents developed by the United Nations, for example the World Programme with a Plan of Action for Human Rights Education (United Nations 2006), have advocated that the treatment of human rights should become an integral part of the education system. It is education that creates close ties between humans, plays the vital role of building a culture of peace and condemning the instances that undermine democracy and tolerance. Education can help to counteract poverty, establish social justice, enforce human rights, exercise democracy, achieve cultural diversity, raise environmental awareness, and promote peace. Promoting peace through education is fundamental to UNESCO's endeavours. According to UNESCO (2005), human rights education is part of the right to education and the knowledge of these rights is a basic tool which guarantees respect for the rights of all. "Human rights education (HRE) is an international movement to promote awareness about the rights accorded by the Universal Declaration of Human Rights and related human rights conventions, and the procedures that exist for the redress of violations of these rights" (Amnesty International 2005, 7). According to Tibbitts (1996) and Reardon (1997), it encompasses training, educational, awareness-raising, and learning activities.

The United Nations Office of the High Commissioner for Human Rights $(1997,5)$ defines human rights education as a part of life-long learning in the following way: 
training, dissemination and information efforts aimed at the building of a universal culture of human rights through the imparting of knowledge and skills and the moulding of attitudes directed to: (a) the strengthening of respect for human rights and fundamental freedoms; (b) the full development of the human personality and the sense of its dignity; (c) the promotion of understanding, tolerance, gender equality and friendship among all nations, indigenous peoples and racial, national, ethnic, religious and linguistic groups; and, (d) the enabling of all persons to participate effectively in a free society.

Felisa Tibbitts, the Co-Founder and Executive Director of Human Rights Education Associates, presents three models for understanding contemporary human rights education practice: from the philosophical-historical point of view, the Values and Awareness Model which applies to social sciences and arts; from the legal-political point of view, the Accountability Model which is applicable in the media, health, and social services; and from the psychological-sociological standpoint, the Transformational Model, applying to human rights as a part of women's development, community development, economic development, and minority rights. These models refer to particular target groups, contents and strategies relating to human development and the social change framework (Tibbitts 2002,163).

The aim of the Values and Awareness Model is to foster critical thinking among learners; the objective of the Accountability Model is to enable development within certain professions and target groups, while the aim of the Transformational Model is to stimulate personal empowerment which leads towards activism for change. Human rights education models can be presented in a modified version of the "learning pyramid": at the bottom, we would find the Values and Awareness Models, in the middle there would be the Accountability Model, and at the top, we could place the Transformational Model. The Values and Awareness Model includes some examples of lessons related to human rights as a part of citizenship, history, social sciences and law-related education classes in schools, and themes related to human rights are integrated into both formal and informal youth programming, such as the arts, Human Rights Day, and debate clubs.

The learning objectives of HRE are threefold: knowledge obtained by learning about human rights; skills developed through learning for human rights; and attitudes or values acquired by learning through and in human rights. When learners are educated in human rights, they acquire numerous desirable skills: they practise active listening, learn how to find information, participate in groups and get organized, develop communication skills, apply critical thinking, use argumentation, recognize prejudices and manipulation, acquire the ability to cooperate and peacefully resolve conflicts, and promote human rights in their local community and globally (Tibbitts and Fernekes 2011).

It is important to understand that human rights education means more than simply disseminating information about human rights. According to Struthers $(2014,55)$ "education must promote respect for these rights", but it can only do so if the teachers choose to apply humanistic principles in their classroom teaching and create a supportive learning environment. In order to educate through human rights, teachers must use every opportunity to show respect for their learners' rights, treat them fairly, allow the learners to express their opinions, make them responsible for their own learning, and earn the learners' respect in return. When the learners are educated through human rights, they develop a sense of responsibility for their own actions, work on their personal growth, awaken their curiosity, keep an open mind, learn to respect differences, to foster/promote solidarity and to support those in danger of human rights violations, as well as develop a sense of dignity, fairness, freedom, equality, and respect. Therefore, human rights 
education not only has much in common with the contemporary education system in general; it is, consequently, education in the broadest sense of the word.

\section{Human Rights Education in Slovene Schools}

Our investigation into whether Slovenian school legislation incorporates any human rights education principles revealed that they are integrated into all of our curricula. While these principles are enshrined in the curricula, as a teacher trainer, I feel that there is still not enough emphasis given to them, especially in foreign language classes, which would be an ideal setting to explore them. This conclusion derives from the premise that education should enable "negotiation between cultures" (Coulby 2016, 246), which reflects one of the main ideas of intercultural education. In foreign language classrooms, of course, two cultures at least are always brought into contact.

The principles of HRE were first explicitly mentioned in the Elementary School Act (Zakon o osnovni šoli 1996) ${ }^{1}$ which lists, among others, the following learning objectives: to educate for mutual tolerance, encourage respect of difference and cooperation with others, respect for human rights and fundamental freedoms, and above all, to promote the ability to live in a democratic society, while also educating for universal cultural values arising from European traditions. Likewise, similar principles are also found in the Grammar Schools Act (Zakon o gimnazijah $2006 / 7)^{2}$ where the following objectives are mentioned: to educate for the responsible protection of freedom, for tolerance, peaceful co-existence and respect for all people; to develop and protect one's own cultural tradition and acquaint oneself with other cultures and civilisations; to educate for universal cultural values arising from European traditions; to develop willingness to establish a free, democratic and socially just country, independent critical judgment and responsible behaviour; and to develop an awareness of human rights and acceptance of responsibilities. As Tibbitts and Fernekes $(2011,91)$ say:

Human rights education in many countries intersects with democratic citizenship education, by taking the core concepts of citizenship education and applying them both more universally and more critically. In that way, knowledge about key concepts and facts and issues of civic disposition and civic skills are applied to the areas of global social responsibility, justice and social action.

In Slovenia, human rights education began with Citizenship Education. In 1995 The White Book on Education in Slovenia was published, determining a new legislation which regulated the entire education system from pre-school up to higher education. Citizenship education was introduced as a compulsory subject in 1996 as 'Citizenship Education and Ethics' at the primary school level, based on a "common European heritage of political, cultural, and moral values" (Šimenc and Sardoč 2013, 366). This was conceived as a cross-curricular topic, a part of other compulsory subjects at the secondary school level, such as history and geography. Furthermore, citizenship education was later included into a compulsory subject called Civic Culture in grade 9 of primary schools and as an optional subject in secondary schools; while in vocational schools, citizenship education is an integral part of social science subjects. Human rights education is thus integrated at all levels, primarily into the work during class periods, but also into various other subjects such as Patriotic and Citizenship Education and Ethics and 
Health Education, and last but not least, and importantly, foreign languages, since they are well suited for addressing the issues of universal cultural and human values. Unlike other subjects, a foreign language is equally new/novel to the learners of different cultural backgrounds; learning it requires extensive communication, negotiation and frequent expressions of opinions, while various interactions promote cooperation and teamwork, and discussion topics can most easily be linked to numerous human rights issues.

At this point it is worth mentioning one of my first generation students, Alenka Elena Begant (1965-2014) who carried out pioneering work by founding the Slovene branch of "Education as an Instrument for Peace (EIP)-School for Peace", which was the first Slovene organisation dedicated to human rights education. In January 2010, she founded the Centre for Citizenship Education. The Centre extended the work of EIP-Slovenia and was also responsible for monitoring local and national elections. She was internationally recognized as an active member of the Slovene branch of Amnesty International and of the Board of Democracy and Human Rights Education in Europe Network (DARE). She participated in HREA, the global human rights education and training centre and her unfulfilled wish was to train more human rights defenders in Slovenia and abroad.

As an English language teacher, she began to integrate the principles of human rights education into her lessons and she often invited student teachers to observe her work with the learners. In addition, she participated in the creation of an interactive learning tool, based on the ideals of human rights, non-discrimination, inclusion, and democracy that was acknowledged by the Organization of Security and Co-operation in Europe (OSCE). Elena also authored, edited and translated many human rights education manuals, including the Council of Europe's "Compass" and Amnesty International's "First Steps" (Human Rights Education Team 1996). She was a great motivator and an inspirational co-worker. Unfortunately, her sudden and untimely death resulted in a significant setback in the development of HR education in our country.

The foundations of human rights education in Slovenia have thus been put in place, so let us examine how it works in practice. Peace education could be considered as a pre-cursor of human rights education. A culture of peace is introduced into our schools from an early age and is developed throughout a life-long process of learning values and skills. Since skills can only be learned through practice, teachers need to promote active and cooperative learning. It seems that the expansion of individualism, violence and the lack of tolerance in the contemporary world make this increasingly difficult. Teachers can only be successful if they have been properly trained, as you cannot teach human rights in a way that contradicts them. Including peace education into our subjects offers a solution to tackling the rising levels of violence; it enables us to reduce impatience and intolerance, it encourages responsibility and promotes the development of intercultural competencies. Therefore, it is crucial to educate our teachers in a way that enables them to address issues such as conflict resolution, violence prevention, cyberbullying, mediation, etc., particularly since this applies to all of our learners, including minority, migrant and also refugee children.

The basic principles of human rights education cover the notions of tolerance, responsibility, identity, equality, justice, freedom, solidarity, security, and peace. Human rights can serve as a basis for the analysis of related principles of practice for inclusion, non-discrimination, and active participation leading to the development of human dignity, diversity and social justice. Human rights activities provide learners with the skills, knowledge and attitudes which they will need to work towards a world free of human rights violations. These factors are incorporated in each of the activities when a participative, interactive educational methodology is used. 
- Knowledge: Learners learn about the existence of human rights documents, try to understand the rights contained in them, which are inalienable and can universally be applied to all human beings, and they become aware of the consequences if/when human rights are violated. This helps them in the protection of their own and other people's rights.

- Skills: Learners learn to listen to others, make moral analyses, cooperate with their peers or partners; they learn how to communicate, solve problems, and to ask questions. This helps them understand the world around them, improve the quality of their and other people's lives and become pro-active in the protection of human rights.

- Attitudes: Learners experience how important human rights are, realise that human dignity is inherent in all people, that everybody's rights should be respected, that cooperation yields better results than the creation of conflicts, that we are responsible for our actions, and that we can improve our world if only we try. This promotes learners' moral development and prepares them for positive actions, as they become more patient or willing to help if their peers cannot cope with the pace of progression, more tolerant of other people's mistakes, and they learn to behave more politely in taking turns.

- Methodology: Participative, interactive methodology enables children to become fully involved in learning. An active learning approach is based on learning from peers and is conductive to critical reflection.

\section{Foreign Language Teaching and Learning}

In a foreign language classroom, learners do not only develop linguistic and communicative competences but also become familiar with other cultures. According to Byram (2008) developing the appropriate skill set to reflect on our own and other cultures provides a basis for respect and increased tolerance, contributes to other ways of thinking, and even broadens learner's understanding of their own cultural belonging. When we are teaching English, pupils can learn about English-speaking countries and cultures, while at the same time they reflect upon their own identity and compare the two. It is interesting to discover that in the process of developing intercultural competence their own identity is even strengthened.

As previously stated, foreign language classrooms seem to be ideal for addressing human rights issues. Language skills can be used to study a plethora of interesting current themes relating to other countries. For example, teachers can use a short text dealing with a campaign against racism in the United States or Great Britain to teach English vocabulary. By doing this, we would pursue the objective of providing students with an understanding of the human rights issues that people are facing in other countries, as well as the knowledge of a foreign language. Teachers can use authentic materials from foreign newspapers, TV and radio news, social networks or literature.

In a foreign language class students have ample opportunities to talk and discuss various issues. Discussion topics such as human rights, values, gender inequality and discrimination, and similar, can stimulate a variety of opinions, which leads to an increase in learners' motivation and a decrease in impatience, thus making learners both more responsible and autonomous, and, consequently more mature. When learners achieve a certain degree of maturity, this enables teachers to use less authoritarian teaching styles and become more relaxed. It is much easier to be kind if the learners respond to politeness and not only to the power of authority.

Apart from discussions, learners also develop their speaking skills by doing role-plays. Role-playing does not only improve student understanding of given situations but also encourages empathy 
and critical thinking (Shapiro 2012; Rivers 2015). The next type of activities recommended for learning the basic principles of human rights are various games and projects where there are many possible acceptable views of the issues and which do not allow only one correct answer. They are played or carried out in groups or teams, requiring the cooperation of all participants, who actively explore the subject matter, not simply passively receiving the teacher's point of view but also revealing and sharing their own feelings and opinions.

In the process of learning a foreign language, it is also customary for learners to correspond with their peers in other countries (A Parcel of English Project, pen pals/friends, and video calls/ conferences). This can be made more interesting if apart from more common, everyday details they also exchange information about political systems, current social issues, the treatment of minorities and any other issues relating to human rights. Unfortunately, many teachers avoid those problematic topics, because of their own fear of creating a conflict situation.

\subsection{Suggestions for Human Rights Teaching Activities}

When teaching human rights, the lesson structure recommended by Prvi koraki (Human Rights Education Team 2009) consists of a warm-up motivation task, usually in the form of brainstorming or open-ended questions, followed by a concrete task, first done individually or in small groups and then as a whole class discussion leading to final conclusions, and ending by a follow-up assignment.

Teachers first select a general topic from a current event (for instance the American elections) or choose an interesting theme (like tolerance) that is prescribed by the curriculum. Then, they need to decide which knowledge, skills, and attitudes they want the students to develop. When they find appropriate teaching materials, they select either more conventional activities such as reading a text and responding to it in a discussion and essay, or less conventional ones like a project, a debate, or writing a story or a poem.

Usually, the biggest problem for the teachers is the evaluation of the learner's performance, since several factors need to be taken into consideration, as we are not only assessing their knowledge but also skills and attitudes. It might be helpful if they consider evaluation criteria which include students' contribution to discussions, their participation in and results of group work activities, and the quality of their assignments. To assess the development of skills and attitudes, we need to evaluate to what extent the learner keeps the task or its purpose in mind, cooperates with group members, works without disturbing others, completes a fair share of work or even finds new ways to improve group work. We might also consider assessing learners' open-mindedness by determining if the learner tries new ways of doing things, considers all sides of an issue, puts facts before feelings in discussions or changes conclusions in the light of new facts. If we really aim at developing values, we must offer our learners a chance to assess themselves and also their peers. The First Steps self-assessment questionnaire requires learners to rate themselves in the following categories (by marking themselves with $\mathrm{A}=$ very $\operatorname{good}, \mathrm{B}=\operatorname{good}, \mathrm{C}=\mathrm{OK}, \mathrm{D}=$ very poor): respect for others, interest in others, listening to others, remaining on task, being sensitive to others' needs, having a fair judgement of others, cooperating with others, thinking before acting, being honest, helping others, and admitting errors. If the learners are involved in a constructive evaluation of themselves and their peers, they tend to become more responsible for their behaviour, and if the results of teacher and learner assessment differ, this provides an excellent opportunity for discussion and negotiation. 


\section{Pre-Service Teacher Training}

Why should teachers be familiar with human rights? Our society becomes more multicultural every day and "the need for human rights education is more urgent than ever" (Osler and Starkey 2010, 26) to promote the ideas/ideals of justice and peace. Human rights educators aim at achieving critical human rights consciousness as their main goal. As teachers, we need to foster critical human rights consciousness which enables students to perceive the human rights dimensions of a problem-oriented exercise, and makes them develop strategies for resolving conflict situations; students must take an active role in the promotion and protection of these rights; they need to acquire the ability to critically evaluate responses, respond creatively, select the most appropriate option, and make responsible decisions with confidence. A multicultural classroom situation is becoming a reality, and it should be fully exploited for its numerous benefits.

So far, Slovene teachers have had ample experience in catering for the needs of minority children, particularly in the mainly bilingual schools along the Italian and Hungarian borders, rendering integration relatively easy. They have also had ample opportunities to work with learners from other ex-Yugoslav republics (Croatians, Serbians, Bosnians, and Albanians from Kosovo) and Roma children, who all have to learn Slovene first in order to be able to participate in class, since neither the teacher nor their classmates share their mother tongue. Discussions with teachers suggest that foreign language classes do not present an obstacle for the migrants' integration, but rather the opposite. Recently, there has been much discussion of our schools accepting and including refugee children, but this time mainly from non-European countries and with radically different cultural backgrounds. Refugee children often feel isolated, alienated, they struggle from discrimination, their fundamental human rights have been violated (Hieronymi 2009), all of which has psycho-social consequences that our teachers should well understand. Since classrooms run on HRE principles are most appropriate for accepting refugee children, teacher education should prepare future teachers for coping with such situations and human rights education principles seem to be the best solution in meeting the need for appropriately trained teachers.

According to Tibbitts $(2002,162)$, HRE programming requires an interactive pedagogical approach: "The language of HRE speaks of being relevant to daily life and to employing methodologies that engage participants in skill, attitudinal, as well as knowledge development". This participatory or interactive teaching approach increases learner's motivation, and is humanising and practical, since the kind of learning it enables more likely leads to changes in behaviour than a pure lecturing approach (ARRC 2003). The following features of pedagogy are representative of those promoted by proponents of HRE (see ARRC 2003; Gollob, Krafp and Weidinger 2010, 32-33):

- Experiential and activity centred: involving the solicitation of learners' prior knowledge and offering activities that draw out learners' experiences and knowledge;

- Problem-posing: challenging the learners' prior knowledge;

- Participative: encouraging collective efforts in clarifying concepts, analysing themes and doing the activities;

- Dialectical: requiring learners to compare their knowledge with those from other sources;

- Analytical: asking learners to think about why things are and how they came to be;

- Healing: promoting human rights in intra-personal and interpersonal relations;

- Strategic thinking-oriented: directing learners to set their own goals and to think of strategic ways of achieving them; 
- Goal- and action-oriented: allowing learners to plan and organise actions in relation to their goals.

Finally, we need to establish to what extent human rights education principles are integrated into the syllabus of Didactics of English courses at the Faculty of Arts. "There is a globalization trend in teacher education, emphasizing the role of teachers to make judgments based on human rights in their teaching profession" (Adami 2014, 30), particularly in the sense of "learning to become' in relation to judgement and justice. It is safe to say that human rights principles are vastly relevant to (future) teachers' work and therefore significantly present in almost every aspect of our syllabus. In combination with the two additional principles of responsibility and accountability, they basically present a framework for teacher's professional practice.

We provide student teachers with various kinds of knowledge: the skills - to be able to compare and interpret; the attitude - to be respectful, tolerant, open-minded and genuinely inquisitive; the ability to acquire new knowledge - to learn how to learn. However, we also equip them with the ability to critically evaluate or interpret learners' beliefs and behaviour. The tasks we carry out make it possible for the student teachers to exercise their intellect, think critically and document or keep track of the changes in their personal and professional development. Let me mention only some of them:

- Profile of a language learner - Student teachers collect the data for an in-depth description of an English learner by first conducting an assessment of the learner's proficiency based on the CEFR self-assessment grid; secondly they establish the learner's learning style and/ or multiple intelligences through a questionnaire, and thirdly, they conduct an interview with the learner on their personal experience as a language learner, their motivation, beliefs about the language and its learning, their autonomy as a language learner, about their achievements and possible problems or difficulties in their language learning as the learner sees them. Lastly, they write a short evaluation of their findings and their work on this assignment which includes their thoughts on a potential support that could be offered to the learner in question or some suggestions to his/her teacher. They also describe how their work on this assignment has influenced or perhaps even changed their views and knowledge of the various factors that affect foreign language learning and have been addressed and discussed during the course. Profiling learners raises student teachers' awareness of the different cultural and social backgrounds of their future learners, teaches them to respect individuality and prepares them to search for different ways of supporting their learners.

- Letter to my teacher - The students' task is to analyse the teaching of one of their English teachers from the viewpoint of some of the principles which characterise English language teaching in the modern world and have been addressed during the course. They write a personal letter to the chosen teacher in which they reflect on and comment on some of the characteristics of that teacher (behaviour, preferred teaching styles and roles, techniques and activities used, patterns of interaction, etc.) and his/her teaching from the viewpoint of the principles, concepts, topics and issues that are conducive to efficient language learning. Special attention is paid to the teacher's behaviour with regard to their respect for human rights and their reactions to conflict situations. They will not, actually, send their letter to the teacher - the form of a personal letter to a particular, real English teacher will allow them to use their experience as a learner and help them support their statements with empirical evidence. 
- And then it happened ... - Report on a critical classroom event. One of the competences that all "good" teachers have and which student teachers need to develop is the ability to respond, in a principled way, to unexpected and problematic events or situations in the classroom. In the modern teaching profession, it has been recognised that these events/ situations (often called 'critical incidents'), if analysed, are a valuable source of information that the (student) teacher can use in order to make principled and effective pedagogical decisions. It needs to be emphasised, however, that 'critical' here does not mean an extreme situation or event. The 'criticalness' of a critical incident will often be discovered only after one has invested enough time and deliberate thinking about the event or situation. Students have to think about the lesson they have just taught and recall one or more events/ situations when something happened which, for some reason, was 'critical' or unexpected in either a positive or negative sense because it influenced the course of the lesson or activity and their teaching. For instance, a learner said or did something which positively (or negatively) influenced the course of a lesson (expressed a radical idea that runs contrary to democratic values or simply rejected other learner's perspectives out of hand); or an activity that they had prepared was too difficult for the learners and needed to be done differently. For the chosen event students provide a detailed description, including their thoughts, feelings, comments and write an evaluation with suggestions for future actions.

- Making the most of your coursebook - Students analyse a coursebook unit with regard to some of the principles of modern post-method language teaching. They think about how a particular learning material relates to one or more of the assumptions of humanistic education, one or more of Kumaravadivelu's macrostrategies, Stevick's criteria for the choice of 'whole-learner' materials and Tomlinson's principles of materials development, Thornbury's 'text-topic-task' strategy, etc. and what problems the teacher might expect when using this particular material in class. Based on their findings, student teachers adjust the chosen coursebook materials to specific learners' needs.

- Reaction paper - Humanising Language Learning - Student teachers critically reflect on the content and ideas contained in an ELT-related academic piece of writing in which the author addresses (presents and discusses) a specific topic, problem, question, or issue within the broader area of teaching and learning. They are referred to ELT-related magazines such as English Teaching Professional, ELT-Journal or on-line journals such as Humanising Language Teaching (http://www.hltmag.co.uk). They do not write a summary of the article but their reaction to it, their personal and professional response to some of the points and the ideas presented by the author.

- Reflective journal - English Didactics Portfolio is a selected collection of student teachers' work and their personal and professional development during a course of study. Basically, creating an EDP means collecting and critically reflecting on student's work and learning during the course, thus providing evidence of their development, both personally and as a future teacher during their studies, especially when compared with their aspirations and set goals. Student teachers are required to write their reflective journal on a weekly basis. A weekly entry should contain their reflections on 2-3 events/situations that happened during this course which they find important, valuable or challenging as a student teacher and a future English teacher. They comment on, question, challenge, or respond to each of these experiences by expressing their thoughts and feelings.

- Selfevaluation - After each lesson, student teachers spend some time reflecting on their experience of putting their plan into action and make notes on interesting details and 
important events, thus creating a starting point for completing a self-evaluation form. Among more obvious issues such as how far the students feel that they have achieved their teaching aims, on what they have based their answer, what has became clearer or what they have learnt; students also describe how satisfied they are with the lesson, how the learners felt during the lesson (interested, relaxed, bored, etc.), what evidence proves that, and in what way their teaching contributed to that; whether they treated all learners as individuals and with respect, tried to include most of them equally, praised the learners for their cooperation and encouraged them, allowed them to express their opinion and really listened to them, resolved conflicts in a peaceful manner, and addressed any cultural differences.

\section{Conclusion}

The paper aimed at addressing firstly, the issues of including human rights education principles into Slovene primary and secondary schools as part of the foreign language learning syllabus, and secondly, at empowering future teachers of English to implement HRE in their teaching. The described tasks and strategies suggest how to enable future teachers to develop not only appropriate attitudes towards their learners but also knowledge and skills through the critical interpretation and evaluation of their learners' beliefs and behaviour, which leads to the creation of a sound framework for their professional practice.

In the teaching profession, we frequently need to make judgments based on human rights; therefore, it is not enough to acquire knowledge about human rights as an addition to the syllabus, human rights education needs must be met as a matter of course in educational institutions. Through human rights education, we can empower teachers and learners to develop the skills and attitudes that promote equality, dignity and respect, not only in the classroom but also in our community, society and worldwide; and consequently, to become better people. We believe that upon conclusion of their studies, our future English teachers are well equipped to become true professionals in their field and successful or efficient educators who will know how to value, respect, and protect all human rights. In conclusion, let me quote Kofi Annan, former secretary general of the United Nations who once said: "Human rights education is much more than a lesson at school or a theme of the day; it is a process to equip people with the tools they need to live the lives of security and dignity."3

\section{References}

Adami, Rebecca. 2014. "Toward Cosmopolitan Ethics in Teacher Education: An Ontological Dimension of Learning Human Rights." Ethics and Education 9 (1): 29-38. doi:10.1080/17449642.2014.890272.

Amnesty International. 2005. Amnesty International Report 2005: The State of the World's Human Rights. London: Amnesty International Publications.

ARRC [Asia-Pacific Regional Resource Center for Human Rights Education]. 2003. What is Human Rights Education? Human Rights Education Pack. Bangkok: ARRC.

Byram, Michael. 2008. From Foreign Language Education to Education for Intercultural Citizenship. Clevedon: Multilingual Matters.

Coulby, David. 2006. “Intercultural Education: Theory and Practice." Intercultural Education 17 (3): 245-57. doi:10.1080/14675980600840274.

3 Speech delivered on Internationational Human Rights Day. Available at: https:/www.amnesty.org/en/latest/ education/2016/02/10-quotes-on-the-power-of-human-rights-education/ 
Council of Europe. 1950. European Convention for the Protection of Human Rights and Fundamental Freedoms, as Amended by Protocols Nos. 11 and 14. Strasbourg: Council of Europe. http://www.echr.coe.int/ Documents/Convention_ENG.pdf.

Cassidy, Claire, Richard Brunner, and Elaine Webster. 2013. “Teaching Human Rights? 'All Hell Will Break Loose!” Education, Citizenship and Social Justice 9 (1): 19-33. doi:10.1177/1746197913475768.

Gollob, Rolf, Peter Krafp, and Wiltrud Weidinger, eds. 2010. Educating for Democracy. Background Materials on Democratic Citizenship and Human Rights Educating for Teachers. Strasbourg: Council of Europe.

Hieronymi, Otto. 2009. "Refugee children and their Future.” Refugee Survey Quarterly 2008: 6-25. doi:10.1093/rsq/hdn058.

Human Rights Education Team. 1996. Partners in Human Rights Education. First Steps: A Manual for Starting Human Rights Education. London: Amnesty International International Secretariat. http://hrlibrary.umn. edu/education/pihre/content.htm.

—. 2009. Prvi koraki: metodični priročnik za poučevanje človekovih pravic. Edited by Kristina Božič and Simona Kemperle. Translated by Alenka Elena Begant et al. Ljubljana: Amnesty International Slovenije. http:// www.amnesty.si/j7/images/UCP/prvi\%20koraki\%20druga\%20izdaja\%20-\%20int.pdf.

Krek, Janez, and Mira Metljak. 2011. Bela knjiga o vzgoji in izobraževanju v Republiki Sloveniji. [The White Paper on Education in Slovenia]. Ljubljana: Zavod RS za šolstvo.

Osler, Audrey, and Hugh Starkey. 2010. Teachers and Human Rights Education. Oakhill: Trentham Books.

Reardon, Betty A. 1997. "Human Rights as Education for Peace." In Human Rights Education for the Twenty-First Century, edited by George J. Andrepoulos and Richard Pierre Claude, 21-34. Philadelphia: University of Pennsylvania Press.

Rivers, Anissa. 2015. "Emphatic Features and Absorption in Fantasy Role-playing." American Journal of Clinical Hypnosis 58 (3): 286-94. doi:10.1080/00029157.2015.1103696.

Shapiro, Shawna, and Lisa Leopold. 2012. "A Critical Role for Role-Playing Pedagogy.” TESL Canada Journal 29 (2): $120-30$.

Struthers, Alison. 2014. "Human Rights Education: Educating about, through and for Human Rights." The International Journal of Human Rights 19 (1): 53-73. doi:10.1080/13642987.2014.986652.

Šimenc, Marjan, and Mitja Sardoč. 2013. “Citizenship Education in Slovenia." In ICCS 2009 Encyclopaedia: Approaches to Civic and Citizenship Education around the World, edited by John Ainley and Wolfram Schulz, 366-68. Amsterdam: IEA.

Tibbitts, Felisa. 1996. “On Human Dignity: A Renewed Call for Human Rights Education.” Social Education 60 (7): 428-31.

—. 2002. "Understanding What We Do: Emerging Models for Human Rights Education." International Review of Education 48 (3-4): 159-71. doi:10.1023/A:1020338300881.

Tibbitts, Felisa, and William R. Fernekes. 2011. Teaching and Studying Social Issues. Major Programs and Approaches. Charlotte, North Carolina: Information Age Publishing.

UNESCO. 2005. “Education. Human Rights Education.” http://www.unesco.org/new/en/education/themes/ leading-the-international-agenda/human-rights-education/.

United Nations. 1997. International Plan of Action for the Decade of Human Rights Education. Geneva: Office of the United Nations High Commissioner for Human Rights.

- 2006. Plan of Action. World Programme for Human Rights Education. First Phase. New York and Geneva: Office of the United Nations High Commissioner for Human Rights. 